\title{
Chapter 5 \\ Youth Labor Underutilization in Australia Following the Global Financial Crisis
}

\author{
Scott Baum \\ iD https://orcid.org/0000-0003-1711-2087 \\ Griffith University, Australia \\ Michael Flanagan \\ University of Newcastle, Australia \\ Bill Mitchell \\ University of Newcastle, Australia
}

\section{ABSTRACT}

In the wake of the Global Financial Crisis, although the Australianeconomy remained largely buoyant in ag gregate terms, outcomes across different groups were notevenly shared. In labor market terms, different demographic groups appeared to more or less impacted by the post-GFC economic environment. One such group were young people, who witnessed a change in employment fortunes compared to others in the labor force. This chapter provides an investigation of these uneven labor market outcomes and presents an analysis of youth labor underutilization using pooled panel data, taking account of both individual level supply-side factors together with the strength of the local labor market (demand-side). The result is an analysis that accounts for the impact of changing macroeconomy, local labor market conditions, and the employability assets of young individuals. The result illustrates the impact of the post-GFC economy of the youth labor market. 


\section{INTRODUCTION}

In the period following the Global Financial Crisis (GFC), there was general agreement that the Australian economy had managed to deflect much of the negative impacts that had seen other international economies suffer from diminished levels of economic growth with serious flow-on effects to labor markets. This resilience was heralded by both the Australian government and international organizations, such as the IMF, as an example of good economic management. According to one Australian media outlet, '[1]uckily in Australia we avoided a long-term unemployment problem - in part due to China, but also because of the massive stimulus program put through by the Rudd Government' (Pickering, 2014). While it is certainly true that the Australian economy managed to remain buoyant while others faltered, it is equally true that in the period following the GFC, changes in the performance and management of the macro-economy have resulted in a gradual diminishing of economic performance across many areas, not least the labor market. Labor market changes extended beyond simply shifts in unemployment and included increases in broader measures of joblessness including underemployment and underutilization, diminishing job security perceptions and changes to the very nature of work. What has been especially concerning has been the long-term impacts on joblessness and employment disadvantage. While all labor sub-markets have been impacted, the impact on the youth labor market has been heightened with significant impacts on the level of both unemployment and underemployment.

Understanding the post-GFC patterns of youth labor underutilization is the focus of this chapter. Its main purpose is to consider the factors associated with youth underutilization including the characteristics of at-risk individuals and the characteristics of the local labor markets and the macro-economy that individuals operate in. The analysis in the chapter provides a unique opportunity to consider the ways that these cross-cutting factors have impacted on labor market outcomes. By utilizing panel data regarding labor market outcomes for individuals aged between 15 and 24 years of age and linking the individual data to broader macro-level factors. The panel data, covering the years 2008 to 2015, is taken from the Household, Income and Labor Dynamics Australia (HILDA) survey and is combined with regional labor market statistics from the Australian Bureau of Statistics. This combined dataset allows the following research questions to be addressed:

1. What was the impact of supply side characteristics on the risk of an individual's labour being underutilised?

2. What was the impact of aggregate/ spatial demand side characteristics on the risk of an individual's labour being underutilised? and 
3. What was the impact of macro-economic forces in the post-GFC period on an individual's labour being underutilised?

\section{LABOR UNDERUTILIZATION AND YOUNG PEOPLE: PATTERNS AND PROBLEMS}

It has been widely acknowledged that in Australia, as elsewhere, the labor market plight of young people aged between 15 and 24 has been increasingly bleak in the period following the Global Financial Crisis. In the period prior to the global downturn, both unemployment and underemployment (and hence underutilization) had been trending lower, a situation that had been in play since the last major downturn of the late 1990s. While there was a sharp increase in all measures in the immediate period of the GFC, the outcomes for young people have continued to deteriorate up until late 2014 and have yet to return to pre-GFC levels. This is despite an improvement in aggregate labor market figures over the same time. Moreover, the post GFC period has seen underemployment taking a larger share of the total underutilization rate than had previously been the case. In terms of magnitudes, the headline unemployment rate moved from $8.9 \%$ prior to the GFC to peak at $14.1 \%$ in November 2014, while underemployment moved from $11.6 \%$ to $17.3 \%$ over the same period. The combined underutilization rate moved from 20.5 per cent prior to the GFC, to a high of 31 per cent at the end of 2014 before declining to the current (Feb 2019) level of 28 per cent (figure 1).

In themselves, these figures provide significant context for exploring the patterns of youth labor market underutilization. However, beyond the actual magnitude of the problem is an acknowledgement that the economic, social and human costs of labor market disadvantage can be significant for individuals involved. While these costs are felt across the spectrum of underutilized labor, they hit young people in particularly significant ways. It is widely recognized that having adequate employment opportunities provide young people with a means of financial and social independence that help contribute to a strong self-identity and positive health and well-being outcomes. For young people not in employment, education or training (NEET) the available research indicates that they have less chances to develop technical and soft skills and tend to be more pessimistic about their futures in the labor market. Reflecting this is the 'scarring 'effect of early labor market disadvantage where negative experiences result in lower life-time earnings, lower levels of human and social capital development and lower levels of job satisfaction (Schmillen \& Umkehrer, 2017). The impact on wage loss has been shown by researchers including Mroz and Savage (2006) who find that prior spells of unemployment can result in a future wage reduction of between 3 and 5 per cent, with the impact tapering off 
Figure 1. Youth unemployment, underemployment and underutilization, Australia, 2007-2019 (trend data) Source: Australian Bureau of Statistics, Labor Force Australia, cat no. 6202.0

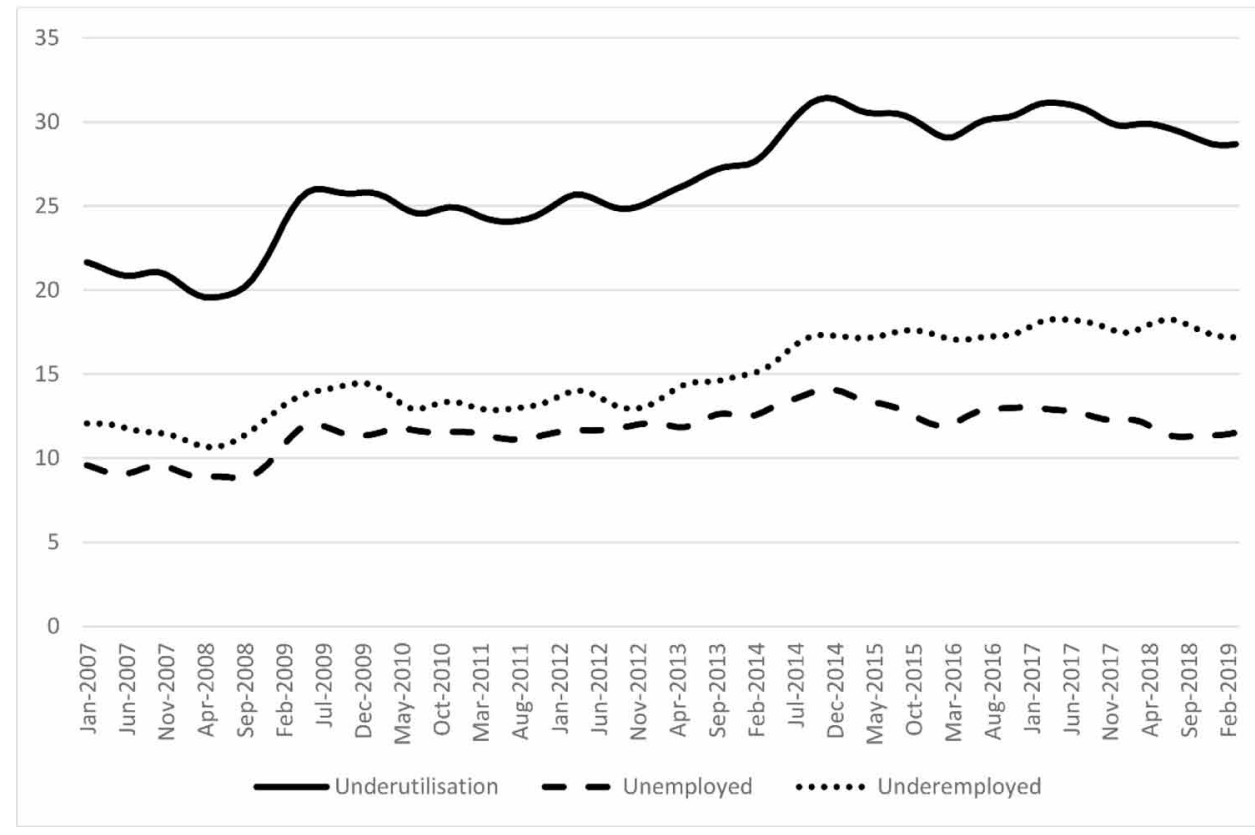

after several years. Scarring is also associated with a higher risk of further labor market disadvantage in later life. While there are mixed findings within the literature, Schmillen and Umkehrer (2017) using data for Germany estimate that 'every day of unemployment during the first eight years of the professional career induces an additional half-day of unemployment during the subsequent 16 years' (p.466).

Early career disadvantage can also impact on health and well-being of young people. Unemployed or underutilized people tend to suffer from poorer health outcomes, report poorer self-rated health and are at a higher risk of mortality (Roelfs et al. 2011). They also tend to have higher incidence of psychiatric and substance abuse disorders than their working peers (Aguilar-Palacio, Carrera-Lasfuentes, \& Rabanaque, 2015; Goldman-Mellor et al., 2016). Illustrating the link between early career disadvantage and health and wellbeing, Helgesson, Johansson, Nordqvist, Lundberg, and Vingård (2012) find that in a sample of young Swedes, being underutilized (unemployed) was linked to an increased risk of sickness, disability and mortality in later life. In a broader systematic review, Vancea and Utzet (2017) find evidence in the majority of studies reviewed that young people are vulnerable to negative health impacts when unemployed or working in precarious conditions. Underutilization can also 
have significant impacts on social networks and social capital, which can in turn reduce feelings of wellbeing and act as a hindrance in finding work. Working with a matched database of German administrative and survey data, Pohlan (2018) provides an illustration showing that as a result of reduced financial resources and the associated psychosocial impacts of not working, unemployment is associated with a loss of social integration and social and cultural participation leading to a reduction in an individual's social networks and social capital. Similar findings are reported by Kunze and Suppa (2017) who, using German panel data, find a negative association between periods of underutilization and social participation in public activities and an associated retreat into private life. They argue that this reduction in social capital as a result of a period of joblessness has significant impacts on future economic outcomes for both the individual concerned and for the wider society.

\section{DETERMINANTS OF YOUTH LABOR UNDERUTILIZATION}

The analysis presented in this chapter is informed by the extensive literature that considers the determinants of labor underutilization. While it has often been the case that research has focused on the characteristics of the individual as they relate to employment, there has been increasing focus on more holistic analytical approaches that consider a wider range of determining factors. Importantly, these have included a focus not only on the characteristics of individuals, but also on the ways in which regional labor market factors may impact on employment outcomes. Taken as part of a broad 'employability' framework labor market outcomes are considered in terms of

the capability to move into and within labor markets and to realize potential through sustainable and accessible employment. For the individual, employability depends on: the knowledge and skills they possess and their attitudes; the way personal attributes are presented in the labor market; the environmental and social context within which work is sought; and the economic context within which work is sought (Department of Higher and Further Education, 2002)

In understanding the determinants of youth labor market outcomes, a range of studies have focused on the socio-economic background and characteristics of individuals as they apply to unemployment or underutilization more generally. Across the individual level, prominent factors have related to an individual's age, their gender, educational attainment, health and family circumstances and/or background. Contemporary work by researchers including Kelly and McGuinness (2015), Marelli and Vakulenko (2016) and Terzo and Giaconia (2019) situates labor market outcomes within the context of the period of the Global Financial Crisis. 
Kelly and McGuinness (2015), considering the impact of the GFC on youth outcomes in Ireland identified that being male, and having post-school qualifications acted to reduce the risk an individual would be classified as being not in employment, education or training (NEET), while being aged 20-24 increased the risk, relative to younger cohorts. Marelli and Vakulenko (2016) looking only at unemployment and modelling data for Italy and Russia identify a positive association between poor health and the risk of being unemployed and inverse relationships between age, being male, being married and having higher education while Terzo and Giaconia (2019) focusing on Italy identify that females, foreigners, those aged less than 20 and those with low education had a much higher risk of labor market disadvantage than others. Other factors seen to be important include the extent of exposure to the paid labor market and the level of social capital an individual possesses. For instance Zwysen (2015) considering identifies the impact of father's employment history on young workers in the United Kingdom, suggesting that a young person's exposure (or lack thereof) to members of the family engaged in the labor market can have a direct link on their own employment outcomes. This intergenerational transfer of employment disadvantage was also identified in recent work by (Vauhkonen, Kallio, Kauppinen, \& Erola, 2017) and the earlier work by (Baum, Bill, \& Mitchell, 2008) in Australia and (O'Neill \& Sweetman, 1998) in the United Kingdom. Social contacts are also likely to be important to overall employment outcomes. Linked to earlier work on social networks and social capital, Hällsten, Edling, and Rydgren (2017) identify the importance of two types of social contacts-the quality of occupational contacts and the extent to which close friends were unemployed-in determining youth labor market disadvantage. Similarly, Aguilera (2002) using the Social Capital Benchmark Survey in the United States showed that friendship networks were positively related to increased participation in the labor force.

Beyond these individual level factors, there has been an increasing awareness of the need to control for regional factors associated with local labor market strength or performance (Baum et al., 2008; Baum \& Mitchell, 2010; Doran \& Fingleton, 2016). In relation to this (Baum \& Mitchell, 2010)argue that research into employment outcomes have often been undertaken either at the micro-level to understand the importance of individual level characteristics or has been undertaken at an aggregate macro or regional level resulting in only a partial understanding of the subject matter. In their research, Baum and Mitchell (2010) identify the importance of local labor market strength, whereby as the level of aggregate unemployment increases in a region (a measure of labor market performance) so to does the risk of individuals being impacted by underutilization. Similarly, the more recent work by (Doran \& Fingleton, 2016), Kelly and McGuinness (2015) and Marelli and Vakulenko (2016) included variables that accounted for the regional variation in labor market performance, finding a positive association between adverse regional performance 
and individual labor market outcomes. Interacting with these spatially differentiated local labor markets is the impact of macro-economic factors such as macroeconomic stability, business confidence and labor demand in the national economy (McQuaid $\&$ Lindsay, 2005). Negative shocks to the macro-economy, such as that witnessed during and immediately after the Global Financial Crisis will work in concert with other factors external to the individual to influence individual labor market outcomes.

\section{ANALYZING THE DETERMINANTS OF YOUTH LABOR UNDERUTILIZATION METHODOLOGY}

To consider the main questions posed in this chapter, we employ two main data sources: (a) the Household, Income and Labor Dynamics in Australia (HILDA) Survey, managed by the Melbourne Institute of Applied Economic and Social Research; and (b) Small Area Labor Markets data for Australia, published by the Australian Commonwealth Department of Employment. The HILDA Survey follows a large cohort of Australians across consecutive years, gathering responses on a variety of economic, social and labor questions. The HILDA Survey began in 2000-01 (Wave 1) and has since produced 16 consecutive waves of output, with a high rate of participant retention. This paper uses data from Waves 8 to 15 (20082015). Among the variables accessed through the HILDA data are a person's labor force status, their age, gender, health status, language command, education level, family status, their parents' employment as well as their social capital. Importantly, the data is accessed from the unconfidentialized release, which allows an individual to be followed through the various waves, and includes a spatial identifier for each individual, which allows placement into an appropriate labor market.

While the retention rate of respondents throughout the life of the survey has been high, some have dropped out along the way, others have missed a year or more along the way, while some do not fully answer all questions in the survey each year. To address this loss of respondents, the Melbourne Institute included a top-up sample in 2012, which increased the number of respondents from then on. However, over the eight years from 2008 to 2015, just over 3,000 respondents answered all questions in every year. Further, this cohort was found to be a biased cohort, with a much higher proportion fully employed and higher education levels than across all respondents over the life of the survey. Hence, we feel there is value in using an unbalanced dataset, where respondents need only to have completed all questions for a single year to remain in the dataset. This does require two consecutive years engagement with the survey at any stage as the social capital variable is sourced from questions from the previous year (see Table 1). 
The Small Area Labor Markets Australia publication produces unemployment and labor force estimates at a small area level, specifically Statistical Areas Level 2 (SA2s) (ABS, 2010). These estimates are based on Australian Bureau of Statistics Labor Force Survey data, which are published at the SA4 level, and then apportioned to SA2s across each SA4 depending on the distribution of unemployment benefit (Newstart and Youth Allowance) recipients in those smaller regions.

\section{LABOR MARKET REGIONS}

The modelling that follows is aimed at evaluating the impact of a person's individual characteristics as well as the characteristics of the labor market they are a part of. We define an individual's labor market as the functional region they live in as per the CofFEE Functional Economic Regions (CFERs) (Stimson, Mitchell, Flanagan, Baum, \& Shyy, 2016). These regions, which cover the whole of Australia, are specifically designed as labor markets, informed by the commuting patterns of workers throughout the country. The regions are unencumbered by administrative or political requirements and have been shown to produce better measures of labor market statistics. This is important as we use the unemployment rate of the region an individual is a resident in as the measure of a region's influence on an individual's labor force status. The CFERs are comprised of SA2s, so a region's unemployment rate is determined by the unemployment and labor force numbers of its constituent SA2s, as provided in the Small Area Labor Markets publication.

\section{MODELLING}

The model is set up to determine the influence a range of individual and regional level explanatory variables have on the response variable, employment status. Employment status for a respondent is divided into one of four categories:

- $\quad$ Fully employed (FE) - employed full-time, or employed part-time without wanting more work;

- $\quad$ Underemployed (UDE) - employed part-time and wanting more work;

- Unemployed (UNE) - not employed and actively looking for work; and

- Marginally attached to the labour force (MALF) - not employed and not actively looking for work but would work if a job became available.

With a categorical dependent variable, the appropriate model to use is a multinomial logit model, with the logit is run so that a base response variable state 
is compared to the other response variable states. To account for the panel nature of the data, the multinomial logit model is altered to introduce individual-specific random effects. This then becomes a mixed logit model, where the parameters are assumed to vary between individuals, thus taking account of the heterogeneity of the population (Croissant, 2013).

The explanatory variables are listed in table 1 below. Most of the explanatory variables are categorical variables where, like the response variable, a baseline reference category is chosen to which all the other categories are compared.

\section{YOUTH LABOR UNDERUTILISATION IN AUSTRALIA: EMPIRICAL FINDINGS}

This section presents the findings from the regression analysis of the labor force status of young people across Australia. Table 2 presents the number and proportion of respondents that comprise the dataset for each wave across the 8 years. The proportion of fully employed young people decreases quite dramatically across the study period, from 66 per cent in 2008, down almost 10 percentage points to 56.7 per cent in 2015 (from 55 per cent in 2014). The drop in fully employed persons is spread evenly across the three measures of labor underutilization, with the largest increase occurring in underemployment among young people over the period.

Table 3 presents the unemployment and underemployment rates of the young people who comprise the dataset and compares them to the corresponding rates across Australia at the time. After the onset of the Global Financial Crisis, the unemployment rate of young people across Australia increased faster than that of the HILDA dataset, but was quite similar once the HILDA top-up sample began (since 2012). The HILDA dataset is over-represented by underemployed young people, but the proportional increase over the 8 years is almost identical to the national level, with the national rate rising 6.6 percentage points and the dataset rising 6.5 percentage points.

Table 4 presents the results of the mixed logit regressions performed for the 15 to 24-year-old cohort in the HILDA dataset and considers the likelihood that a young person is unemployed, underemployed or marginally attached to the labor force compared to being fully employed.

The characteristics that raised the probability of being underemployed relative to being fully employed are presented in the first results column of table 4 . Given the existing literature it is not surprising that several individual level factors significantly increase the risk of underemployment for young people. Compared to males, young females are more likely to be underemployed than in any of the other labor force states. A long-term health condition among young people increases their chances of 


\section{Table 1. Independent variables}

\begin{tabular}{|c|c|c|}
\hline Variable & Description & Reference Variable \\
\hline Sex & 1 if person $i$ is female at time $t ; 0$ otherwise & Person is male at time $t$ \\
\hline Poor Health & $\begin{array}{l}1 \text { if person } i \text { reports a long-term health condition at } \\
\text { time } t ; 0 \text { otherwise }\end{array}$ & $\begin{array}{l}\text { No long-term health condition } \\
\text { reported at time } t\end{array}$ \\
\hline Non-English & $\begin{array}{l}1 \text { if person } i \text { was born in a non-English speaking } \\
\text { country; } 0 \text { otherwise }\end{array}$ & $\begin{array}{l}\text { Person born in English } \\
\text { speaking country }\end{array}$ \\
\hline Post-secondary & $\begin{array}{l}1 \text { if person } i \text { 's highest level of education at time } t \\
\text { is post-secondary (inc certificate and diploma); } 0 \\
\text { otherwise }\end{array}$ & $\begin{array}{l}\text { Person has no post-school } \\
\text { qualification at time } t\end{array}$ \\
\hline Tertiary & $\begin{array}{l}1 \text { if person } i \text { has completed tertiary level education } \\
\text { at time } t \text { (bachelor degree and above); } 0 \text { otherwise }\end{array}$ & $\begin{array}{l}\text { Person has no post-school } \\
\text { qualification at time } t\end{array}$ \\
\hline $\begin{array}{l}\text { Couple relationship } \\
\text { with children }\end{array}$ & $\begin{array}{l}1 \text { if person } i \text { is part of a couple relationship with } \\
\text { dependent children at time } t ; 0 \text { otherwise }\end{array}$ & Person is single at time $t$ \\
\hline $\begin{array}{l}\text { Single parent } \\
\text { family }\end{array}$ & 1 if person $i$ is a single parent at time $t ; 0$ otherwise & Person is single at time $t$ \\
\hline $\begin{array}{l}\text { Couple no } \\
\text { dependents }\end{array}$ & $\begin{array}{l}1 \text { if person } i \text { is part of a couple with no dependent } \\
\text { children at time } t ; 0 \text { otherwise }\end{array}$ & Person is single at time $t$ \\
\hline Parents unemployed & $\begin{array}{l}1 \text { if both parents of person } i \text { were not in paid } \\
\text { employment when person } i \text { was } 14 ; 0 \text { otherwise }\end{array}$ & $\begin{array}{l}\text { At least one of person's parents } \\
\text { were in paid employment when } \\
14\end{array}$ \\
\hline $\begin{array}{l}\text { Previous } \\
\text { employment }\end{array}$ & $\begin{array}{l}1 \text { if person } i \text { did not have a job anytime in the } \\
\text { previous } 12 \text { months at time } t ; 0 \text { otherwise }\end{array}$ & $\begin{array}{l}\text { Person had a job some time in } \\
\text { last } 12 \text { months }\end{array}$ \\
\hline Social Capital & $\begin{array}{l}\text { Social capital/networks value for person } i \text { at } \\
\text { time } t-1 \text {. This was calculated through a Principal } \\
\text { Components Analysis of responses to } 9 \text { questions } \\
\text { from HILDA survey }\end{array}$ & N/A \\
\hline $\begin{array}{l}\text { Regional } \\
\text { unemployment }\end{array}$ & $\begin{array}{l}\text { Log of the unemployment rate of the region } \\
(\text { CFER) person } i \text { is resident in at time } t\end{array}$ & N/A \\
\hline Year2 & 1 if period is time 2 (2009), 0 otherwise & Year 1 (2008) \\
\hline Year3 & 1 if period is time 3 (2010), 0 otherwise & Year 1 (2008) \\
\hline Year4 & 1 if period is time 4 (2011), 0 otherwise & Year 1 (2008) \\
\hline Year5 & 1 if period is time 5 (2012), 0 otherwise & Year 1 (2008) \\
\hline Year6 & 1 if period is time 6 (2013), 0 otherwise & Year 1 (2008) \\
\hline Year7 & 1 if period is time 7 (2014), 0 otherwise & Year 1 (2008) \\
\hline Year8 & 1 if period is time 8 (2015), 0 otherwise & Year 1 (2008) \\
\hline
\end{tabular}

being underemployed as opposed to being fully employed, as does being born in a Non-English-speaking country. An individual's household or family characteristics also play a part in mediating the risk of unemployment. Whether a young person has children has a significant impact on their employment chances. A young person who is part of a couple with children or who is a single parent is more likely to 
Youth Labor Underutilization in Australia Following the Global Financial Crisis

Table 2. Dataset labor force status statistics

\begin{tabular}{|c|c|c|c|c|c|c|}
\hline Year & & Fully employed & $\begin{array}{l}\text { Under- } \\
\text { employed }\end{array}$ & Unemployed & $\begin{array}{l}\text { Marginally } \\
\text { Attached LF }\end{array}$ & Total \\
\hline \multirow{2}{*}{2008} & Number & 911 & 210 & 113 & 146 & 1,380 \\
\hline & Proportion & $66.0 \%$ & $15.2 \%$ & $8.2 \%$ & $10.6 \%$ & $100 \%$ \\
\hline \multirow{2}{*}{2009} & Number & 893 & 234 & 126 & 151 & 1,404 \\
\hline & Proportion & $63.6 \%$ & $16.7 \%$ & $9.0 \%$ & $10.8 \%$ & $100 \%$ \\
\hline \multirow{2}{*}{2010} & Number & 921 & 233 & 133 & 187 & 1,474 \\
\hline & Proportion & $62.5 \%$ & $15.8 \%$ & $9.0 \%$ & $12.7 \%$ & $100 \%$ \\
\hline \multirow{2}{*}{2011} & Number & 931 & 288 & 132 & 177 & 1,528 \\
\hline & Proportion & $60.9 \%$ & $18.8 \%$ & $8.6 \%$ & $11.6 \%$ & 1005 \\
\hline \multirow{2}{*}{2012} & Number & 1,103 & 312 & 188 & 218 & 1,821 \\
\hline & Proportion & $60.6 \%$ & $17.1 \%$ & $10.3 \%$ & $12.0 \%$ & $100 \%$ \\
\hline \multirow{2}{*}{2013} & Number & 1,097 & 338 & 184 & 214 & 1,860 \\
\hline & Proportion & $59.0 \%$ & $18.2 \%$ & $9.9 \%$ & $13.0 \%$ & $100 \%$ \\
\hline \multirow{2}{*}{2014} & Number & 1,021 & 371 & 206 & 250 & 1,848 \\
\hline & Proportion & $55.2 \%$ & $20.1 \%$ & $11.1 \%$ & $13.5 \%$ & $100 \%$ \\
\hline \multirow{2}{*}{2015} & Number & 1,041 & 350 & 204 & 240 & 1,835 \\
\hline & Proportion & $56.7 \%$ & $19.1 \%$ & $11.1 \%$ & $13.1 \%$ & $100 \%$ \\
\hline \multirow{2}{*}{ All years } & Number & 7,918 & 2,336 & 1,286 & 1,610 & 13,150 \\
\hline & Proportion & $60.2 \%$ & $17.8 \%$ & $9.8 \%$ & $12.2 \%$ & $100 \%$ \\
\hline
\end{tabular}

Source: HILDA Survey, authors' calculations

Table 3. Underutilization rates, the dataset and Australia compared

\begin{tabular}{|l|l|l|l|l|}
\hline \multicolumn{1}{|c|}{ Year } & \multicolumn{2}{c|}{ Unemployment Rate } & \multicolumn{2}{c|}{ Underemployment Rate } \\
\hline & \multicolumn{1}{|c|}{ Dataset } & \multicolumn{1}{c|}{ Australia } & \multicolumn{1}{c|}{ Dataset } & \multicolumn{1}{c|}{ Australia } \\
\hline 2008 & $9.2 \%$ & $9.3 \%$ & $18.7 \%$ & $13.4 \%$ \\
\hline 2009 & $10.1 \%$ & $11.5 \%$ & $20.8 \%$ & $16.5 \%$ \\
\hline 2010 & $10.3 \%$ & $11.5 \%$ & $20.2 \%$ & $15.5 \%$ \\
\hline 2011 & $9.8 \%$ & $11.4 \%$ & $23.6 \%$ & $15.0 \%$ \\
\hline 2012 & $11.7 \%$ & $11.5 \%$ & $22.0 \%$ & $14.7 \%$ \\
\hline 2013 & $11.4 \%$ & $12.1 \%$ & $23.6 \%$ & $17.0 \%$ \\
\hline 2014 & $12.9 \%$ & $14.2 \%$ & $26.7 \%$ & $20.1 \%$ \\
\hline 2015 & $12.8 \%$ & $12.1 \%$ & $25.2 \%$ & $20.0 \%$ \\
\hline
\end{tabular}

Source: HILDA Survey, authors' calculations, ABS Labor Force Survey

Note: Underemployment rate is underemployed persons as a proportion of all employed persons 
be underemployed than fully employed, compared to a single person. In contrast, a young person who is part of a couple without children is more likely to be fully employed than to be underemployed.

A young person's level of education has important impacts on the risk of underemployed. Having some form of post-secondary education, either an immediate post-school diploma or certificate or a tertiary degree or higher degree reduces the risk of being underemployed. A young person's social capital and networks has a large impact on their labor force status. The higher a person's social capital the more likely they are to be fully employed than to be underemployed.

For the risk of underemployment, the impact of geographical location is important. In particular, living in a labor market region with a higher unemployment rate increases the risk that a young person will be underemployed rather than fully employed. Finally, despite the increase in labor underutilization among young people as the effects of the Global Financial Crisis became embedded in the macroeconomy, the individual years after 2008 did not have much of an impact on a young person's risk of underemployment. In only two years (2011 and 2014) was a young person more likely to be underemployed than fully employed, compared to 2008 .

Results column 2 of table 4 presents the results for the risk of being unemployed relative to being fully employed. Like the previous category, the results indicate that for young people, several individual level factors are associated with the risk of being unemployed relative to being fully employed. While the variables accounting for sex and country of birth are insignificant in explaining unemployment outcomes, having poor health is significant. The coefficient on the variable 'poor-health' indicates that a young person with a long-term health condition is significantly more likely to be unemployed than to be fully employed. As expected, education level is an important determinant in the likelihood of being unemployed. Having either a non-tertiary secondary education or a tertiary education significantly mediates the risk of being unemployed for young people., as does currently being in a couple relationship with no children.

The employment history of a young person's parents has a noteworthy impact on their own employment. If a young person's parents were not in employment when they were 14 years, they are more likely to be out of work themselves than employed, compared to someone who had at least one parent in employment when they 14 years. A young person's social capital and networks has a large impact on their labor force status. The higher a person's social capital the more likely they are to be fully employed than be unemployed. Like underemployment, the risk that a young person will be unemployed is impacted by geographical location. As the unemployment rate in the labor market region increases, so does the risk that a young person will be unemployed rather than fully employed. 
The final set of results (column 3 table 4) compare marginal labor market attachment relative to being fully employed. While the sex of an individual does not significantly impact on the risk of being marginally attached, health status and country of birth is important. For young people, having a long-term health condition or being born in a non-English speaking country increases the risk of being marginally attached rather than being fully employed. As with previous categories, education level is important in the case of being marginally attached. Those with any postschool qualification, tertiary or otherwise, are more likely to be fully employed than marginally attached, compared to those without a post-school qualification. The presence of children, either in a couple relationship or a single parent is associated with an increased likelihood that a young person will be marginally attached, rather than fully employed. In contrast, the absence of children reduces the likelihood.

As with the previous results, the employment history of a young person's parents has a significant impact on their own employment outcomes. If a young person's parents were not in employment when they were 14 years, they are more likely to be marginally attached to the labor market than employed. A young person's social capital and networks also has an impact on their labor force status. The higher a person's social capital the more likely they are to be fully employed than be marginally attached. Unlike the previous categories of employment outcomes, being marginally attached rather than fully employed is not impacted by either the strength of the labor market region or the broader macro-economic conditions.

\section{CONCLUSION}

This chapter sets out an analysis of youth labor underutilization in Australia in the years following the Global Financial Crisis (GFC). The context for the chapter lies in the realization that while the Australian economy was resilient in the early phases of the GFC, deterioration in the macro-economy in later years has resulted in declining labor market performance, even as other economies were showing improvement. Considering youth labor underutilization as a function of individual characteristics, including social and family contexts, the strength of the local labor market region and the performance of the macro-economy the analysis considers three separate, but interrelated questions:

1. What was the impact of supply side characteristics on the risk of an individual's labour being underutilised?

2. What was the impact of aggregate/ spatial demand side characteristics on the risk of an individual's labour being underutilised? and 
Table 4. Regression analysis results. Likelihood of being underemployed, unemployed or marginally attached compared to being fully employed

\begin{tabular}{|c|c|c|c|}
\hline & $\begin{array}{l}\text { Underemployed relative to } \\
\text { fully employed }\end{array}$ & $\begin{array}{l}\text { Unemployed } \\
\text { relative to fully } \\
\text { employed }\end{array}$ & $\begin{array}{c}\text { Marginally } \\
\text { attached relative to } \\
\text { fully employed }\end{array}$ \\
\hline Intercept & $-2.539 * * *$ & $-3.202 * * *$ & $-3.102 * * *$ \\
\hline Sex (Female) & $0.367 * * *$ & -0.141 & 0.060 \\
\hline Poor Health & $0.420 * * *$ & $0.716 * * *$ & $0.838 * * *$ \\
\hline Non-English & $0.361 *$ & 0.167 & $0.667 * * *$ \\
\hline Post-secondary & $-0.335 * * *$ & $-0.359 * *$ & $-0.976 * * *$ \\
\hline Tertiary & $-0.634 * * *$ & $-0.726 * * *$ & $-0.667 * * *$ \\
\hline $\begin{array}{l}\text { Couple relationship with } \\
\text { children }\end{array}$ & $0.417 * * *$ & -0.102 & $0.418 * * *$ \\
\hline Single parent family & $0.555 * * *$ & 0.234 & $0.764 * * *$ \\
\hline Couple no dependents & $-0.325 * * *$ & $-0.313 *$ & $-0.744 * * *$ \\
\hline Parents unemployed & 0.152 & $0.881 * * *$ & $1.089 * * *$ \\
\hline Previous employment & 0.992 & 19.312 & 19.957 \\
\hline Social Capital & $-0.045 * * *$ & $-0.088 * * *$ & $-0.073 * * *$ \\
\hline Regional unemployment & $10.41 * * *$ & $8.251 * *$ & 0.904 \\
\hline Year2 & 0.063 & 0.023 & -0.044 \\
\hline Year3 & -0.005 & -0.032 & 0.042 \\
\hline Year4 & $0.254 *$ & 0.030 & 0.137 \\
\hline Year5 & 0.132 & 0.180 & 0.065 \\
\hline Year6 & 0.186 & 0.033 & 0.126 \\
\hline Year7 & $0.343 * *$ & 0.092 & 0.040 \\
\hline Year8 & 0.227 & -0.003 & -0.127 \\
\hline
\end{tabular}

Source: HILDA Survey, DoE Small Area Labor Markets, authors' calculations

Note: $* * * \mathrm{p}<0.001 ; * * \mathrm{p}<0.01 ; * \mathrm{p}<0.05$

3. What was the impact of macro-economic forces in the post-GFC period on an individual's labour being underutilised?

It is not surprising, given the established literature dealing with youth labor underutilization, to find that individual characteristics such as formal education, gender, language proficiency and health status are implicated in the risk that a young person will be disadvantaged in the labor market. Capabilities, measured by formal education, physical capacity and health and language capacity, all impact on the likelihood of a young person being underutilized with low capabilities being 
associated with increased disadvantage. Lastly, there is a significant gendered difference in the likelihood of underutilization, with females more likely to be underemployed by hours or marginally attached, a finding that reflects both choices around workforce participation and family and also about gendered constraints in labor markets ((Christensen, 2015; Périvier, 2018).

Over and above these individual employability characteristics, social and family context variables were also important. Reflecting the impacts of life cycle choices and constraints (Crompton \& Harris, 1998; Steiber \& Haas, 2012), individuals who were members of a couple only household were less likely to be underutilized across all outcomes, while those in couple households with children present had a higher likelihood of being underemployed or marginally attached to the labor market. Family relationships with work are also important. Individuals who grew up in job-poor families were more likely to be unemployed or have marginal labor force attachment reflecting the potential impacts of intergenerational transfers of disadvantage (Berloffa et al., 2016). Beyond the family, broader social networks are also associated with labor underutilization with those with low measures of social capital being more likely to be in one of the underutilization categories.

The second question addressed in this chapter related to the role that spatial demand-side characteristics have on the likelihood that an individual would be classified as being underutilized. There is clear evidence presented here that regardless of other factors, a young person's labor market outcomes are influenced by the level of local labor demand. In areas with job deficiencies the risk of being underemployed or unemployed was significantly higher than in regions with stronger local labor markets.

The final question addressed in this chapter related to the impact of the macroeconomy on labor underutilization outcomes, and the impact of the deteriorating post-GFC economy. If we take 2010 as the beginning of the broader international recovery macro-economic deterioration continued in the Australian economy resulting in worsening labor market outcomes. Interestingly, this deterioration in the Australian macro-economy coincided with the end of the Federal Government's fiscal assistance programs and the beginning of austerity politics. Despite this, there was only limited impact on youth labor market outcomes from these measured changes in the wider macro economy.

If one of the reasons for analyzing the drivers of individual labor underutilization is to contribute to policy debates, the findings of this paper provide a useful addition to the labor market evidence base. The impact of individual level characteristics on underutilization may be evidence of the need to improve an individual's employment capacity through place neutral policies such as skills training schemes. This has certainly been a focus of a significant amount of Australia labor market policy in the past. However, as has been pointed out elsewhere (Baum et al., 2008), a focus 
on these people based or place neutral polices can only be seen as a necessary but not sufficient condition towards improving labor market outcomes. A focus on the strength and performance of local labor markets through place-based policies will provide demand side approaches that complement polices targeting things like skills improvement. The final take-home message from this paper relates to the Government's responsibility to act as an enabler for inclusion of individuals into all aspects of society including the paid labor market. While there is significant discussion in policy circles about individuals taking more responsibility for their own outcomes, as has been shown here and elsewhere (Baum et al., 2008), the government must actively pursue polices to ensure that broad economic and policy contexts are favorable towards positive labor market outcomes for all.

\section{REFERENCES}

Aguilar-Palacio, I., Carrera-Lasfuentes, P., \& Rabanaque, M. J. (2015). Youth unemployment and economic recession in Spain: Influence on health and lifestyles in young people (16-24 years old). International Journal of Public Health, 60(4), 427-435. doi:10.100700038-015-0668-9 PMID:25724155

Aguilera, M. B. (2002). The impact of social capital on labor force participation: Evidence from the 2000 Social Capital Benchmark Survey. Social Science Quarterly, 83(3), 853-874. doi:10.1111/1540-6237.00118

Baum, S., Bill, A., \& Mitchell, W. (2008). Labour underutilisation in metropolitan labour markets in Australia: Individual characteristics, personal circumstances and local labour markets. Urban Studies (Edinburgh, Scotland), 45(5-6), 1193-1216. doi:10.1177/0042098008089865

Baum, S., \& Mitchell, W. F. (2010). People, space and place: A multidimensional analysis of unemployment in metropolitan labour markets. Geographical Research, 48(1), 13-23. doi:10.1111/j.1745-5871.2009.00620.x

Berloffa, G., Filandri, M., Matteazzi, E., Nazio, T., Negri, N., O’Reilly, J., . . . Zuccotti, C. (2016). Work-poor and work-rich families: Influence on youth labour market outcomes. Academic Press.

Christensen, K. (2015). He-cession? She-cession? The gendered impact of the great recession in the United States. The Review of Radical Political Economics, 47(3), 368-388. doi:10.1177/0486613414542771 
Crompton, R., \& Harris, F. (1998). Explaining women's employment patterns:'orientations to work'revisited. The British Journal of Sociology, 49(1), 118-136. doi:10.2307/591266 PMID:9569774

Department of Higher and Further Education. (2002). Report of the Taskforce on Employability and Long-Term Unemployment. Author.

Doran, J., \& Fingleton, B. (2016). Employment resilience in Europe and the 2008 economic crisis: Insights from micro-level data. Regional Studies, 50(4), 644-656.

Goldman-Mellor, S., Caspi, A., Arseneault, L., Ajala, N., Ambler, A., Danese, A., ... Williams, T. (2016). Committed to work but vulnerable: Self-perceptions and mental health in NEET 18-year olds from a contemporary British cohort. Journal of Child Psychology and Psychiatry, and Allied Disciplines, 57(2), 196-203. doi:10.1111/ jcpp.12459 PMID:26791344

Hällsten, M., Edling, C., \& Rydgren, J. (2017). Social capital, friendship networks, and youth unemployment. Social Science Research, 61, 234-250. doi:10.1016/j. ssresearch.2016.06.017 PMID:27886731

Helgesson, M., Johansson, B., Nordqvist, T., Lundberg, I., \& Vingård, E. (2012). Unemployment at a young age and later sickness absence, disability pension and death in native Swedes and immigrants. European Journal of Public Health, 23(4), 606-610. doi:10.1093/eurpub/cks099 PMID:22930745

Kelly, E., \& McGuinness, S. (2015). Impact of the Great Recession on unemployed and NEET individuals' labour market transitions in Ireland. Economic Systems, 39(1), 59-71. doi:10.1016/j.ecosys.2014.06.004

Kunze, L., \& Suppa, N. (2017). Bowling alone or bowling at all? The effect of unemployment on social participation. Journal of Economic Behavior \& Organization, 133, 213-235. doi:10.1016/j.jebo.2016.11.012

Marelli, E., \& Vakulenko, E. (2016). Youth unemployment in Italy and Russia: Aggregate trends and individual determinants. Economic and Labour Relations Review, 27(3), 387-405. doi:10.1177/1035304616657959

McQuaid, R. W., \& Lindsay, C. (2005). The concept of employability. Urban Studies (Edinburgh, Scotland), 42(2), 197-219. doi:10.1080/0042098042000316100

Mroz, T. A., \& Savage, T. H. (2006). The long-term effects of youth unemployment. The Journal of Human Resources, 41(2), 259-293. doi:10.3368/jhr.XLI.2.259 
O’Neill, D., \& Sweetman, O. (1998). Intergenerational mobility in Britain: Evidence from unemployment patterns. Oxford Bulletin of Economics and Statistics, 60(4), 431-447. doi:10.1111/1468-0084.00108

Périvier, H. (2018). Recession, austerity and gender: A comparison of eight European labour markets. International Labour Review, 157(1), 1-37. doi:10.1111/ilr.12032

Pickering, C. (2014, 11 June). Lessons for Australia from the GFC. The Australian. Retrieved from https:/www.theaustralian.com.au/business/business-spectator/newsstory/lessons-for-australia-from-the-gfc/f6a0682272988717ad5b5d7c919190d7

Pohlan, L. (2018). Unemployment and social exclusion. Academic Press.

Schmillen, A., \& Umkehrer, M. J. I. L. R. (2017). The scars of youth: Effects of early-career unemployment on future unemployment experience. Academic Press.

Steiber, N., \& Haas, B. (2012). Advances in explaining women's employment patterns. Socio-economic Review, 10(2), 343-367. doi:10.1093er/mwr039

Stimson, R., Mitchell, W., Flanagan, M., Baum, S., \& Shyy, T.-K.(2016). Demarcating functional economic regions across Australia differentiated by work participation categories. Australasian Journal of Regional Studies, 22(1), 27.

Terzo, G., \& Giaconia, C. (2019). The socio-demographic determinants of youth unemployment in Italy: Evidences from national labour survey. Paper presented at the EconWorld2018, Seville, Spain.

Vancea,M., \& Utzet, M.(2017). How unemployment and precarious employment affect the health of young people: A scoping study on social determinants. Scandinavian Journal of Public Health, 45(1), 73-84. doi:10.1177/1403494816679555 PMID:27885160

Vauhkonen, T., Kallio, J., Kauppinen, T. M., \& Erola, J. (2017). Intergenerational accumulation of social disadvantages across generations in young adulthood. Research in Social Stratification and Mobility, 48, 42-52. doi:10.1016/j.rssm.2017.02.001

Zwysen, W. (2015). The effects of father's worklessness on young adults in the UK. IZA Journal of European Labor Studies, 4(1), 2. doi:10.1186/2193-9012-4-2 


\section{KEY TERMS AND DEFINITIONS}

Employment Scarring: The long-term social and economic impact of a period of joblessness on an individual.

Labor Demand Factors: Factors such as the strength of local labor markets or firms hiring practices that impact on the demand for labor.

Labor Supply Factors: Factors such as an individual's education, health, sex, ethnic background or age that impact on the supply of labor.

Labor Underutilization: The state of employment disadvantage associated with either unemployment, under-employment or marginal labor force attachment.

Marginal Labor Force Attachment: The characterization of a person who is not working and not actively looking for work but would take a job if one became available.

Social Capital: Networks of relationships among people who live in a society.

Underemployment: The characterization of a person who is working but employed part time and wanting more hours (underemployed by hours) or a worker who is not making full use of their skills and abilities (underemployment by skills).

Unemployment: The characterization of a person who is not working, bout is actively looking for work. Does not include people who are characterized as marginally attached. 